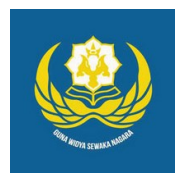

Jurnal Analogi Hukum

Journal Homepage: https://ejournal.warmadewa.ac.id/index.php/analogihukum

\title{
Pengenaan Pajak Pada Perjanjian Pengikatan Jual Beli Hak Atas Tanah
}

\author{
Nadia Githa Wijaya*, I PT. GD. Seputra dan Luh Putu Suryani \\ Universitas Warmadewa, Denpasar-Bali, Indonesia \\ *githawijaya@gmail.com
}

How To Cite:

Wijaya, N, G., Seputra, I, P, G., Suryani, L, P. (2021). Pengenaan Pajak Pada Perjanjian Pengikatan Jual Beli Hak. Jurnal Analogi Hukum. 3 (1). 6-10. Doi: https://doi.org/10.22225/ah.3.1.2923.6-10

\begin{abstract}
Buying and selling is an deal between the parties about paying a certain price of an item, with the aim of transferring ownership rights. in achieving legal certainty in the sale and purchase of land rights, the parties are bound by an agreement based on an agreement made before a notary. Considering Government Ordinance Number 24 of 1997 concerning Land Registration, the transfer of rights to land only arises after the issuance of a sale and purchase deed by the Land Deed Official, then vague norm arises related imposition of tax in the binding agreement on the sale and purchase of land rights. The formulation of the problem: 1 . What is the process of binding agreement on the sale and purchase of land rights related to imposition of tax? 2. What is the form of tax imposition in the agreement to buy and sell rights to land? The research method used was Normative/Literature. Binding agreement on the sale and purchase of land rights is a pre-agreement made because it relates to the imposition of tax in the case of a transfer of rights to land that must be paid in advance to order carry out transactions in the Land Deed Official. The tax imposed in the binding agreement on the sale and purchase of land rights is the income tax for the seller and the Cost of Acquiring Land and/or Building Rights for the buyer.
\end{abstract}

Keywords: Agreement On Binding Of Sale And Purchase; Imposition Of Tax, Agreement On Binding Of Sale And Purchase; Land Rights

\begin{abstract}
Abstrak - Jual beli merupakan suatu kesepakatan antara para pihak tentang membayar harga tertentu dari suatu barang, dengan tujuan mengalihkan hak milik atas kebendaan yang dijual. Dalam mencapai kepastian hukum dalam jual beli hak atas tanah, para pihak diikat dengan suatu perjanjian berdasarkan kesepakatan yang di buat di hadapan notaris. Mengingat PP No. 24 / 1997 mengenai Pendaftaran Tanah, peralihan hak atas tanah barulah timbul setelah diterbitkannya akta jual beli oleh Pejabat Pembuat Akta Tanah, maka timbul kekaburan norma terkait dengan pengenaan pajak dalam perjanjian pengikatan jual beli hak atas tanah. Maka rumusan masalahnya: 1. Bagaimana proses perjanjian pengikatan jual beli hak atas tanah terkait dengan pengenaan pajak? 2. Bagaimana bentuk pengenaan pajak dalam perjanjian pengikatan jual beli hak atas tanah? Metode penelitian yang digunakan adalah Normatif/Kepustakaan. Perjanjian pengikatan jual beli hak atas tanah merupakan pra-perjanjian yang dibuat karena terkait dengan pengenaan pajak dalam hal peralihan hak atas tanah yang harus di bayarkan terlebih dahulu agar dapat melakukan transkasi jual beli di hadapan Pejabat Pembuat Akta Tanah. Pajak yang dikenakan dari perjanjian pengikatan jual beli hak atas tanah ialah pajak penghasilan bagi pihak penjual dan Bea Perolehan Hak Atas Tanah Dan/Atau Bangunan bagi pihak pembeli.
\end{abstract}

Kata Kunci: Perjanjian Pengikatan Jual Beli; Pengenaan Pajak; ak Atas Tanah

\section{Pendahuluan}

Indonesia merupakan Negara hukum, maka segala tindakan maupun perbuatan yang dilakukan di wilayah Indonesia memilki aturanaturan yang diatur oleh hukum, misalnya seperti Perjanjian. Persetujuan, Perjanjian yang sah artinya adalah Ditentukan, yang memenuhi syarat-syarat yang telah oleh undang-undang, sehingga ia diakui oleh hukum (Muhammad, 1982). Lebih lanjut, Subekti menyatakan Perjanjian merupakan suatu peristiwa di mana seseorang berjanji kepada orang lain atau di mana dua orang itu saling berjanji untuk melaksanakan sesuatu hal (Subekti, 1991). Dalam pelaksanaan perjanjian kadangkala mengalami hambatan, artinya isi perjanjian tidak dapat dilaksanakan. Hal ini dapat terjadi 
karena salah satu pihak ingkar janji atau wanprestasi atau keduanya ingkar janji (Prasetyo, 2017). Masyarakat di Indonesian dalam melakukan perjanjian masih banyak yang melakukan dengan perjanjian lisan, walaupun perjanjian lisan tidak dilarang oleh $\mathrm{KUH}$ Perdata namun, perjanjian lisan tidak memiliki kekuatan hukum yang kuat dibandingkan perjanjian dalam bentuk tertulis (Gumanti, 2012). Untuk memberikan kepastian hukum maka dalam hal pengaturan kesepakatan dalam perjanjian diperlukan pejabat umum yang berwenang untuk membuat perjanjian, sehingga perjanjian tersebut memiliki kepastian hukum yang dapat dipertanggungjawabkan.

Setiap perjanjian yang dilaksanakan oleh masyarakat pada akhirnya akan bermuara di notaris, karena setiap perjanjian yang buat dan di sahkan oleh notaris memiliki kekuatan hukum yang mengikat bagi para pihak yang melakukannya. salah satu perjanjian yang dibuat oleh notaris ialah perjanjian pengikatan jual beli atau disebut juga PPJB. Berdasarkan Pendapat R. Subekti yang dimaksud dengan PPJB merupakan perjanjian yang dibuat untuk penjual dan untuk pembeli sebelum dilakukannya jual beli, hal ini disebabkan karena dalam jual beli memiliki beberapa unsur -unsur yang harus dilengkapi terlebih dahulu. Seperti contoh, misalkan sertifikat hak atas tanah tersebut tidak ada, dikarenakan masih digunakan untuk proses sesuatu, ataupun belum berlangsungnya pembayaran terhadap harga atau pajak-pajak yang dikenakan untuk jual beli hak atas tanah, yang belum bisa dibayar bagi penjual atau pembeli (Subekti, 1998).

Namun dalam hal Pemindahan hak atas tanah, Pejabat Pembuat Akta Tanah (PPAT) memiliki kewenangan mengenai hal peralihan hak ini dengan diterbitkannya Akta Jual Beli (AJB), sehingga timbul pertanyaan mengenai letak keabsahan pengenaan pajak pada tahap PPJB hak atas tanah. Hal ini dikarenakan, penerapan transaksi jual beli hak atas tanah dimana pada tahap pengikatan para pihak telah dikenakan atau dibebani dengan pajak, baik pajak penjual dan pajak pembeli.

Berlandaskan penjabaran pada latar belakang diatas, maka dirumuskan permasalahan, yaitu :

Bagaimana proses perjanjian pengikatan jual beli hak atas tanah terkait dengan pengenaan pajak?

Bagaimana bentuk pengenaan pajak dalam perjanjian pengikatan jual beli hak atas tanah?
Yang mana tujuan pengkajian ini, yaitu:

Guna mengerti dan memahami proses perjanjian pengikatan jual-beli hak atas tanah terkait pengenaan pajaknya

Guna mengetahui dan memahami bentuk pengenaan pajak di dalam perjanjian pengikatan jual beli hak atas tanah

\section{Metode}

metode yang penulis gunakan untuk pengkajian ini ialah metode penelitian hukum normatif/ kepustakaan yang mana pengkajiannya berdasarkan atas bahan-bahan hukum dari literatur terkait, dan dalam pembahasannya dilakukan dengan memakai dua pendekatan masalah yaitu, pendekatan perundang-undangan juga pendekatan konseptual. Pendekatan perundang-undangan adalah penelaahan semua peraturan perundangundangan yang terkait dengan permasalahan (isu hukum) yang sedang dihadapi. Sedangkan pendekatan konseptual ialah pendekatan yang menilik mengenai pandangan-pandangan maupun doktrin-doktrin yang berkembang dalam ilmu hukum.

Adapun sumber bahan hukum yang digunakan dalam penelitian hukum normatif ini, bersumber dari penelitian kepustakaan (Library Research) dengan bahan-bahan hukum sebagai berikut, berupa :

Bahan hukum primer yang merupakan peraturan perundang-undangan yang terdiri dari Undang-Undang Dasar Negara Republik Indonesia Tahun 1945; Kitab Undang-undang Hukum Perdata (BW); Undang-Undang Nomor 5 Tahun 1960 Tentang Peraturan Dasar PokokPokok Agraria; Undang-Undang Nomor 17 Tahun 2000 Tentang Perubahan Ketiga Atas Undang-Undang Nomor 7 Tahun 1983 Tentang Pajak Penghasilan; Undang-Undang Nomor 28 Tahun 2009 tentang Pajak Daerah dan Retribusi Daerah; Undang-Undang Nomor 2 Tahun 2014 Tentang Perubahan atas Undang-Undang Nomor 30 Tahun 2004 Tentang Jabatan Notaris; PP No. 24 Tahun 1997 Tentang Pendaftaran Tanah; PP No. 34 Tahun 2016 Tentang Pajak Penghasilan Atas Penghasilan dari Pengalihan Hak Atas Tanah dan/atau Bangunan, dan Perjanjian Pengikatan Jual Beli Atas Tanah dan/atau Bangunan Beserta Perubahannya.

Adapun Bahan Hukum kedua yaitu Bahan hukum Sekunder, yang diperoleh melalui penelitian kepustakaan (Library research), yang dapat berupa buku-buku, jurnal ilmiah, hasil penelitian ahli, media-massa/ surat kabar dan 
juga sumber dari internet yang berkaitan dengan pengenaan pajak pada tahap pengikatan perjanjian jual beli hak atas tanah.

Bahan hukum Tersier, yaitu penelitian kepustakaan (Library research) yang dapat berupa kamus hukum, kamus besar bahasa Indonesia, Black Law Dictionary, ensiklopedia, dan ilmu lain yang berkaitan dengan penelitian ini.

Teknik pengumpulan dari semua bahan hukum tersebut diproses melalui pengklasifikasian terhadap semua bahan hukum; membaca; melakukan pencatatan bahan hukum primer dan bahan hukum sekunder serta melakukan sistematika seluruh bahan-bahan hukum yang telah terkumpul yang berkaitan dengan permasalahan ini yang berkenaan dengan pengenaan pajak pada PPJB dalam hal hak atas tanah.

\section{Hasil Penelitian dan Pembahasan}

\section{Proses Perjanjian Pengikatan Jual Beli Hak Atas Tanah Terkait dengan Pengenaan Pajak}

Pada dasarnya perjanjian lahir dari suatu perikatan yang ditimbulkan dari kesepakan antara satu orang dengan orang lainnya untuk melakukan suatu hal tertentu. Beberapa asasasas dalam hukum Perjanjian meliputi asas konsensualitas, asas kekuatan mengikat, asas kebebasan berkontrak, dan asas kepribadian. Lebih lanjut, agar sebuah perjanjian dapat memiliki keabsahan di mata hukum, maka harus mencerminkan ketentuan dalam Pasal 1320 Kitab Undang-Undang Hukum Perdata. Sehingga jika perjanjian telah memenuhi keabsahan dalam hal syarat sah perjanjian, maka perjanjian tersebut memiliki kekuatan yang mengikat bagi para pihak, maka perjanjian tersebut wajib dilakukan dengan itikad baik. Bentuk-bentuk dari perjanjian ini dibedakan menjadi dua yaitu perjanjian tidak tertulis (lisan) dan perjanjian tertulis, kedua bentuk perjanjian ini memiliki kekuatan mengikat jika memenuhi syarat - syarat sah perjanjian, Namun dalam prakteknya perjanjian tidak tertulis (lisan) kurang digemari, karena perjanjian tidak tertulis (lisan) sulit untuk dibuktikan jika terjadi permasalahan hukum di kemudian hari. Sedangkan perjanjian dalam bentuk tertulis memiliki 2 jenis, yaitu perjanjian otentik dan perjanjian dibawah tangan. Dalam kehidupan bermasyarakat, manusia sebagai makhluk sosial yang bersifat sosial atau dikenal dengan makhluk Zoonpoliticon, tidak akan bisa hidup tanpa orang lain, melainkan hidup secara berkelompok atau sebagai sebuah masyarakat.
Pada kehidupan manusia yang bermasyarakat tersebut dijumpai adanya kehidupan sosial yang penuh damai, harmonis dan bahagia. Salah satu pemenuhan kebutuhan hidup manusia di masyarakat maka sering dijumpai terjadinya tindakan jual beli dalam memenuhi kebutuhan hidup manusia bermasyarakat tersebut. Dimana perbuatan jual beli memiliki dua (2) sifat, yaitu Jual beli bersifat konsensuil, yang berarti ketika para pihak sepakat mengenai suatu hal yang diperjanjikan maka jual beli dianggap telah terjadi dan Jual beli bersifat obligatoir, dikatakan jual beli belumlah terjadi pemindahan atas hak milik, karena jual beli tersebut baru memberikan hak dan meletakkan kewajiban kepada kedua belah pihak. Perjanjian Pengikatan Jual Beli selanjutnya disebut sebagai PPJB yang merupakan perjanjian pendahuluan yang dibuat sebelum dilaksanakannya perjanjian utama atau perjanjian pokoknya (Salim, 2017). Sehingga dapat dikatakan bahwa PPJB ini merupakan pra -perjanjian. Tujuan dari PPJB hak atas tanah adalah agar dapat dilakukan pengecekan sertifikat, pengecekan zona atau nilai tanah yang mempengaruhi pembayaran Pajak Bumi dan Bangunan (PBB), dan juga untuk mengetahui seberapa besar pembayaran Pajak Penghasilan (PPh) untuk pihak penjual dan Bea Perolehan Hak Atas Tanah Dan/ Atau Bangunan (BPHTB) untuk pihak pembeli. Pengenaan pajak ini diatur dalam Pasal 1 ayat (3) PP No. 34 Tahun 2016. Secara Normatif Pengenaan pajak ini dikenakan apabila dalam proses PPJB hak atas tanah tersebut, harga yang disepakati telah terbayar lunas sehingga terjadinya levering atau pemindahan hak atas tanah yang diperjual belikan yang dibuktikan dengan Akta Jual Beli (AJB). Proses PPJB Atau Pra-Perjanjian ini tidak menutup kemungkinan adanya pembatalan perjanjian, pembatalan ini bisa disebabkan karena tidak dibayar lunasnya objek yang diperjual belikan sesuai tempo waktu yang telah disepakati atau adanya sengketa terhadap objek yang diperjual belikan. Maka dapat dikatakan juga bahwa objek dari Bea Perolehan Hak Atas Tanah Dan/Atau Bangunan (BPHTB) ialah PPJB yang sudah dilakukan namun kesepakatan terhadap harga hak atas tanah tersebut belum terbayar, atau belum dibuatnya suatu PPJB hak atas tanah, namun objek perjanjian tersebut telah dibayar lunas. Ataupun sistem pembayaran dari objek PPJB terhadap hak atas tanah tersebut diproses melalui cara bertahap/ dicicil.

\section{Bentuk Pengenaan Pajak dalam Perjanjian Pengikatan Jual Beli Hak Atas Tanah}


Untuk mencapai cita-cita atau harapan guna tercapainya kemajuan suatu Negara, maka diperlukan pembiayaan yang besar untuk menunjang perencanaan yang dirancang oleh pemerintah, sehingga untuk memperoleh pembiayaan tersebut, suatu Negara memperoleh penghasilannya melalui pungutan pajak, dan/ atau dari hasil kekayaan alam yang ada di dalam negerinya. Memperhatikan pertumbuhan ekonomi yang semakin pesat pada zaman ini, juga berimbas terhadap daya beli masyarakat yang tinggi misalnya saja seperti daya beli masyarakat terhadap hak atas tanah, yangmana dalam hal proses peralihan hak atas tanah dan/ atau bangunan inipun dapat berlangsung karena jual beli, hibah, waris, tukar menukar, dan lelang. Dengan demikian, akibat dari proses peralihan tersebut berdampak pula terhadap pengenaan pajaknya. Proses peralihan hak atas tanah dan/atau bangunan berkaitan erat dengan kepastian hukum guna manjadi bukti sehingga hak tersebut dapat dipertahankan dihadapan semua pihak, dan dalam prosesnya menimbulkan adanya hak dan kewajiban bagi pihak yang mengalihkan maupun pihak yang menerima peralihan hak tersebut. Pajak yang berkaitan erat dengan perbuatan hukum dalam peralihan hak atas tanah dan/ atau bangunan, dimana lebih dikhusus kepada jual beli ialah Pajak Penghasilan yang selanjutnya disingkat sebagai $\mathrm{PPh}$ dan Bea Perolehan Hak Atas Tanah Dan/ Atau Bangunan yang selanjutnya disingkat sebagai BPHTB, Subjek dari BPHTB ialah subjek hukum yang terdiri dari orang pribadi atau badan yang memperoleh hak atas tanah dan/ atau bangunan. Mengenai objeknya adalah perolehan hak atas tanah dan/ atau bangunan, dimana penerimaan hak itu meliputi jual beli, tukar menukar, hibah, hibah wasiat, waris, dan seterusnya. Sedangkan subjek dari $\mathrm{PPh}$ ialah orang pribadi, warisan yang belum terbagi, badan dan bentuk usaha tetap. Objek dari $\mathrm{PPh}$ yaitu setiap penambahan kemampuan atau kesanggupan ekonomi yang diterima maupun diperoleh wajib pajak baik yang berasal dari luar negeri ataupun dalam negeri yang dapat digunakan sebagai tambahan kekayaan oleh wajib pajak. Dalam pengenaan BPHTB di PPJB hak atas tanah, pengenaan pajaknya berdasarkan Nilai Perolehan Objek Pajak selanjutnya disebut NPOP atau Nilai Pasar adalah sebagai dasar pengenaan dari BPHTB, dimana NPOP atau Nilai Pasar dari jual beli ialah sesuai harga kesepakatan kedua belah pihak dan jika NPOP belum ada/ diketahui, atau harga dari NPOP atau nilai pasar tersebut di bawah harga Nilai Jual Objek Pajak selanjutnya disebut NJOP, maka dasar pengenaan yang dipakai untuk membayar pajak bumi dan bangunan adalah NJOP. NJOP atau NPOP tersebut nantinya dikurangin Nilai Perolehan Objek Pajak Tidak Kena Pajak (NPOPTKP) ditetapkan paling rendah sebesar enam puluh juta rupiah bagi setiap wajib pajak, hal ini diatur dalam peraturan daerah sehingga pada setiap daerah memungkinkan terjadi perbedaan nilai nominal NPOPTKP. Pengenaan tarif BPHTB ditentukan pengenaannya paling besar lima persen $(5 \%)$, dalam hal terutang BPHTB dalam transaksi jual beli dapat terjadi ketika pada saat tanggal dibuatnya dan ditandatanganinya perjanjian tersebut. Pengenaan PPh dalam PPJB Hak atas tanah sebesar dua koma lima persen $(2,5 \%)$ berdasarkan jumlah pengahasilan kotor dari nilai pengalihan hak atas tanah dan/ atau bangunan. Meskipun saat pengenaan pajak dikatakan bahwa subjek dari objek pajak dapat dikenakan pajak, apabila telah terjadi peralihan hak dari pihak pertama (penjual) menjadi hak atas tanah pihak kedua (pembeli), Tetapi dalam PPJB hak atas tanah bolehlah dikatakan bahwa belum terjadinya peralihan hak tersebut, oleh karena pada tahap ini baru terjadi pengikatan hanya mengenai hak dan kewajiban bagi para pihak, seperti yang telah dijabarkan diatas bahwa sifat dari Perjanjian Pengikatan Jual Beli (PPJB) ini bersifat konsensuil dan obligatoir. Memperhatikan PP No. 24 Tahun 1997 mengenai Pendaftaran Tanah, timbulnya peralihan hak tersebut baru dimulai saat ditandatanganinya Akta Jual Beli (AJB) oleh pejabat yang berwenang, Hal ini dipertegas juga dalam Undang-Undang Nomor 5 Tahun 1960 Tentang Peraturan Dasar Pokok-Pokok Agraria, dimana dinyatakan dalam pengalihan barang tidak bergerak terjadi pada saat dikeluarkannya Akta Jual Beli (AJB) oleh Pejabat Pembuat Akta Tanah (PPAT) (Subekti, 1991).

\section{Simpulan}

Adapun kesimpulan dari pembahasan yang telah di paparkan tersebut diatas, yakni : Proses PPJB hak atas tanah ialah sebuah perjanjian pendahuluan atau pra-perjanjian dalam rangka terjadinya jual beli hak atas tanah yang terjadi dalam masyarakat, PPJB hak atas tanah dibuat karena terkait dengan pengenaan pajak dalam hal peralihan hak atas tanah yangmana pihak penjual harus membayarkan $\mathrm{PPh}$ dan pihak pembeli diwajibkan membayar BPHTB terlebih dahulu agar dapat melakukan transkasi jual beli di hadapan Pejabat Pembuat Akta Tanah (PPAT). Perjanjian Pengikatan ini berfungsi sebagai perjanjian pengikat apabila dikemudian hari terjadi permasalah seperti PPJB yang sudah dibuat namun kesepakatan terhadap harga hak atas tanah tersebut belum terbayar, atau belum dibuatnya suatu PPJB hak atas tanah, namun objek perjanjian tersebut telah dibayar lunas. 
Ataupun sistem pembayaran dari objek PPJB hak atas tanah tersebut dilakukan dengan cara bertahap/dicicil.

Bentuk pengenaan pajak dari PPJB hak atas tanah ini jika dilihat secara normatif bentuk pengenaan pajak dapat dilakukan apabila PPJB hak atas tanah sudah terjadi pemindahan hak dan kewajiban yang disertai dengan penyerahan / levering dimana levering ini secara yuridis dibuktikan dengan Akta Jual Beli (AJB). Maka pajak yang dikenakan ialah $\mathrm{PPh}$ bagi pihak penjual dan BPHTB terhadap pihak pembeli. Namun dengan adanya UndangUndang Nomor 28 tahun 2009, serta PP No. 34 Tahun 2016. PPJB sudah diakui untuk dikenakan pajak bagi para pihak, hal ini disebabkan agar jangan sampai para pihak terhindar dari transaksi jual beli yang sudah dibayarkan pajaknya. Sehingga para pihak yang sudah membayarkan pajak tersebut mendapatkan perlindungan hukum.

\section{DAFTAR PUSTAKA}

Gumanti, R. (2012). Syarat Sahnya Perjanjian (Ditinjau Dari KUHPerdata). Jurnal Pelangi Ilmu, 5(1). Retrieved from http://ejurnal.ung.ac.id/index.php/JPI/ article/view/900

Muhammad, A. K. (1982). Hukum Perikatan. Bandung: Alumni.

Prasetyo, H. (2017). Pembaharuan Hukum Perjanjian Sportentertainment Berbasis Nilai Keadilan (Studi Kasus Pada Petinju Profesional di Indonesia). Jurnal Pembaharuan Hukum, 4(1). Retrieved from http://jurnal.unissula.ac.id/ index.php/PH/article/download/1645/ pdf\#: :text=Perjanjian diatur dalam Kitab Undang,satu orang lain atau lebih.

Salim, H. S. (2017). Teknik Pembuatan Akta Perjanjian (TPA DUA). Jakarta: P.T. Raja Grafindo Persada.

Subekti, R. (1991). Hukum Perjanjian. Jakarta: P.T. Intermasa.

Subekti, R. (1998). Aspek-Aspek Hukum Perikatan Nasional. Bandung: Citra Aditya Bakti. 